ARTICLE

https://doi.org/10.1038/s41467-019-12052-5

\title{
Soybean antiviral immunity conferred by dsRNase targets the viral replication complex
}

\author{
Kazuhiro Ishibashi (1) 1, Masayasu Saruta2,8, Takehiko Shimizu³,9, Miao Shu', Toyoaki Anai ${ }^{4}$, \\ Kunihiko Komatsu ${ }^{5,10}$, Naohiro Yamada ${ }^{6}$, Yuichi Katayose ${ }^{7,11}$, Masayuki Ishikawa ${ }^{1}$, Masao Ishimoto ${ }^{3,12}$ \& \\ Akito Kaga ${ }^{3}$
}

Eukaryotic positive-strand RNA viruses replicate their genomes in membranous compartments formed in a host cell, which sequesters the dsRNA replication intermediate from antiviral immune surveillance. Here, we find that soybean has developed a way to overcome this sequestration. We report the positional cloning of the broad-spectrum soybean mosaic virus resistance gene Rsv4, which encodes an RNase $\mathrm{H}$ family protein with dsRNA-degrading activity. An active-site mutant of Rsv4 is incapable of inhibiting virus multiplication and is associated with an active viral RNA polymerase complex in infected cells. These results suggest that Rsv4 enters the viral replication compartment and degrades viral dsRNA. Inspired by this model, we design three plant-gene-derived dsRNases that can inhibit the multiplication of the respective target viruses. These findings suggest a method for developing crops resistant to any target positive-strand RNA virus by fusion of endogenous host genes.

\footnotetext{
${ }^{1}$ Plant and Microbial Research Unit, Division of Plant and Microbial Sciences, Institute of Agrobiological Sciences, National Agriculture and Food Research Organization, 2-1-2 Kannondai, Tsukuba, Ibaraki 305-8602, Japan. ${ }^{2}$ Crop Breeding and Food Functional Components Division, Western Region Agricultural Research Center, National Agriculture and Food Research Organization, 1-3-1 Senyu-cho, Zentsuji-shi, Kagawa 765-8508, Japan. ${ }^{3}$ Soybean and Field Crop Applied Genomics Research Unit, Institute of Crop Science, National Agriculture and Food Research Organization, 2-1-2 Kannondai, Tsukuba, Ibaraki 3058518, Japan. ${ }^{4}$ Faculty of Agriculture, Saga University, 1 Honjo-machi, Saga 840-8502, Japan. ${ }^{5}$ Research Team for Crop Cold Tolerance, Hokkaido Agricultural Research Center, National Agriculture and Food Research Organization, Hitsujigaoka 1, Toyohira, Sapporo, Hokkaido 062-8555, Japan. ${ }^{6}$ Nagano Vegetable and Ornamental Crops Experiment Station, 1066-1, Soga, Shiojiri, Nagano 399-6461, Japan. 7 Advanced Genomics Breeding Section, Institute of Crop Science, National Agriculture and Food Research Organization, 1-2 Ohwashi, Tsukuba, Ibaraki 305-8634, Japan. ${ }^{8}$ Present address: Soybean Breeding Unit, Institute of Crop Science, National Agriculture and Food Research Organization, 2-1-2 Kannondai, Tsukuba, Ibaraki 305-8518, Japan. ${ }^{9}$ Present address: Advanced Genomics Breeding Section, Institute of Crop Science, National Agriculture and Food Research Organization, 2-1-2 Kannondai, Tsukuba, Ibaraki 305-8518, Japan. ${ }^{10}$ Present address: Crop Breeding and Food Functional Components Division, Western Region Agricultural Research Center, National Agriculture and Food Research Organization, 1-3-1 Senyu-cho, Zentsuji-shi, Kagawa 765-8508, Japan. ${ }^{11}$ Present address: Department of Planning and Coordination, National Agriculture and Food Research Organization, 3-1-1 Kannondai, Tsukuba, Ibaraki 305-8517, Japan. ${ }^{12}$ Present address: Division of Basic Research, Institute of Crop Science, National Agriculture and Food Research Organization, 3-1-1 Kannondai, Tsukuba, Ibaraki 305-8517, Japan.

Correspondence and requests for materials should be addressed to A.K. (email: kaga@affrc.go.jp)
} 
E ukaryotes have evolved several layers of antiviral defense systems. Double-stranded (ds) RNA is a virus-specific molecular pattern recognized by hosts that triggers innate immunity or RNA silencing ${ }^{1}$. In plants, dsRNAs produced by either viral or plant endogenous RNA-dependent RNA polymerases (RdRp) are processed by the Dicer-like RNase III proteins to generate 21-nt to 24-nt small interfering (si) RNAs. siRNAs are incorporated into Argonaute proteins to make an RNA-induced silencing complex (RISC), which cleaves RNAs having sequences complementary to the siRNA ${ }^{2}$. To counteract RNA silencing by the host, viruses encode suppressors of RNA silencing, many of which bind siRNA and prevent RISC formation ${ }^{2}$.

In addition to the RNA-silencing-mediated basal resistance, plants have genes that confer resistance to specific viruses. Most virus resistance genes in plants encode nucleotide binding site-leucine-rich repeat (NB-LRR) proteins that elicit a defense reaction upon recognition of pathogens ${ }^{3}$. Other virus resistance genes encode structurally unrelated proteins with various functions ${ }^{3}$. Resistance genes have been introduced into crops to protect them from viral diseases; however, the available resistance genes cover only a limited range of viruses.

The genus Potyvirus in the family Potyviridae, a family of positive-strand RNA viruses, includes many economically important crop viruses such as Potato virus Y (PVY), Turnip mosaic virus (TuMV), and Plum pox virus (PPV). Potyviruses are transmitted by aphids, and their genome encodes a large polyprotein that is processed into ten or eleven proteins ${ }^{4}$. To protect from potyviruses, resistance genes have been introduced into many crop cultivars such as potato ${ }^{5}$, pepper ${ }^{6}$, papaya ${ }^{7}$, plum $^{8}$, Brassica crops ${ }^{9}$, and legumes ${ }^{10}$.

Soybean mosaic virus (SMV) is a potyvirus that reduces soybean yields and seed quality worldwide ${ }^{11,12}$. Four dominant SMV resistance genes have been found in soybean accessions and introduced into commercial cultivars. Rsv1, Rsv3, and Rsv5 are strain-specific and are suggested to encode NB-LRR proteins ${ }^{13-17}$. In contrast, Rsv4 confers broad-spectrum resistance to SMV strains through an atypical mechanism that delays SMV multiplication ${ }^{18}$. In this study, we aim to clone the $R s v 4$ gene and elucidate the resistance mechanism. The mechanism of Rsv4mediated SMV resistance deepens our knowledge of the virus-host arms race and inspire us to develop a method to engineer virus-resistant organisms by fusion of endogenous host genes.

\section{Results}

Positional cloning of the SMV resistance gene Rsv4. Here, we report positional cloning of Rsv4 (Fig. 1a, Supplementary Fig. 1). Using 9320 progenies of a cross between soybean cultivars Peking (Rsv4; resistant) and Enrei (rsv4; susceptible), we mapped the gene within a 9.8-kbp region on soybean chromosome 2 , adjacent to the Rsv4 region previously mapped by other groups ${ }^{19-21}$. In this region of Enrei and the SMV-susceptible cultivar Williams 82, two tandemly repeated homologous open reading frames (ORFs; NM_001249088 and NM_001253944) were found (Fig. 1a). Both ORFs contain an intron and encode RNase H-like proteins (Supplementary Fig. 1c, d). In contrast, a 3.6-kbp deletion was found in this region of the Peking genome, and only a single ORF that encodes a 259-amino-acid protein was found (Fig. 1a, Supplementary Fig. 1). The predicted protein from the Peking ORF has an RNase H-like domain and a transmembrane helix (Fig. 1b). Transgenic soybean plants overexpressing this RNase $\mathrm{H}$ family protein from Peking showed resistance to all tested SMV strains except for SMV-L(Q1033K), a mutant SMV that has an amino acid substitution in the P3 cistron and can multiply more rapidly than its parental strain in $R s v 4$ plants 22 (Fig. 2a-c). Thus, this RNase $\mathrm{H}$ family protein inhibits SMV multiplication with the same virus specificity seen in Rsv4 soybean lines. Following ethyl methanesulfonate (EMS) mutagenesis of Peking, we isolated four independent mutant alleles of this RNase $\mathrm{H}$ family gene and found that three of them conferred recessive susceptibility to strain SMV-C (Fig. 2d, Supplementary Table 1, Supplementary Fig. 2). We conclude that the Rsv4 gene encodes this RNase $\mathrm{H}$ family protein.

The 3.6-kbp deletion identified in resistant cultivar Peking was rare in cultivated soybean but was found in Chinese and Korean soybean (Glycine max) landraces and more frequently in Glycine soja, the wild progenitor of soybean (Fig. 3). All of the resistant accessions we examined contained the 3.6-kbp deletion. On the other hand, there were susceptible accessions both with and without the 3.6-kbp deletion, indicating that it did not always confer SMV resistance (Supplementary Fig. 3). We further classified 63 soybean accessions that carried the 3.6-kbp deletion into 16 types based on amino acid sequence (Supplementary Figs. 3 and 4). A close relationship was observed between amino acid sequence and a degree of SMV CP accumulations, providing supporting evidence that the gene encoding the RNase family protein is Rsv4. The predicted Rsv4 protein sequences of Beeson (PI548510 ${ }^{23}$ and PI88788 ${ }^{18}$, which are both resistant to SMV but reported to have different $R s v 4$ alleles, differed at 3 and 16 positions, respectively, from that of Peking and V94-5152 (PI596752) ${ }^{19}$ (Supplementary Fig. 4). The SMV-C resistance of Fukusennari was mapped to the Rsv4 region by using progenies of a cross with Enrei, but its sequence is different from those of Peking, Beeson, and PI88788 (Supplementary Figs. 3 and 4). The syntenic regions in other legume genomes contain complex arrangements of RNase $\mathrm{H}$ genes, suggesting the prevalence of genomic rearrangements at this locus (Supplementary Fig. 5). While RNase $\mathrm{H}$ proteins are universally encoded in plant genomes, the N-terminal transmembrane helix, such as found in Rsv4, is unique to legume RNase $\mathrm{H}$ proteins.

Rsv4 is a dsRNase interacting with SMV replication machinery. The Rsv4 protein contains a DEDN motif in which the fourth residue of the DEDD motif in the active site of many RNase $\mathrm{H}$ proteins ${ }^{24}$ is changed from aspartate to asparagine (Fig. 1b). We introduced a mutation into Rsv4 to substitute the first D of the DEDN motif with N (D99N). Transient expression of Rsv4 by agroinfiltration inhibited SMV multiplication in Nicotiana benthamiana but the Rsv4(D99N) mutant did not (Fig. 2e), suggesting that resistance depends on an activity of the RNase $\mathrm{H}$-like domain. When Agrobacterium containing a wild-type Rsv4 construct was infiltrated at high concentrations, virus multiplication was inhibited even for SMV-L(Q1033K) (Fig. 2f), indicating that overexpression of Rsv4 can increase the durability of the resistance. In the $N$. benthamiana transient overexpression system, one of the two ORFs from Jack (susceptible), NM_001249088, inhibited SMV multiplication while the inhibitory activity was weaker than Rsv4 when Agrobacterium concentration was low (Supplementary Fig. 6a). NM_001249088 mRNA was expressed at similar or slightly higher levels to Rsv4 in soybean leaves (Supplementary Fig. 6b). These results suggest that NM_001249088 encodes a functional antiviral protein but that the effects of its endogenous expression in soybean have been overcome by SMV.

Although the canonical function of RNase $\mathrm{H}$ is to degrade RNA strands of DNA-RNA hybrids, no DNA-RNA hybrid is formed during positive-strand RNA virus replication ${ }^{25}$. We thus investigated the substrate preference of Rsv4. Purified FLAGtagged Rsv4 protein degraded neither single-strand RNA nor a 
a

Chromosome 2

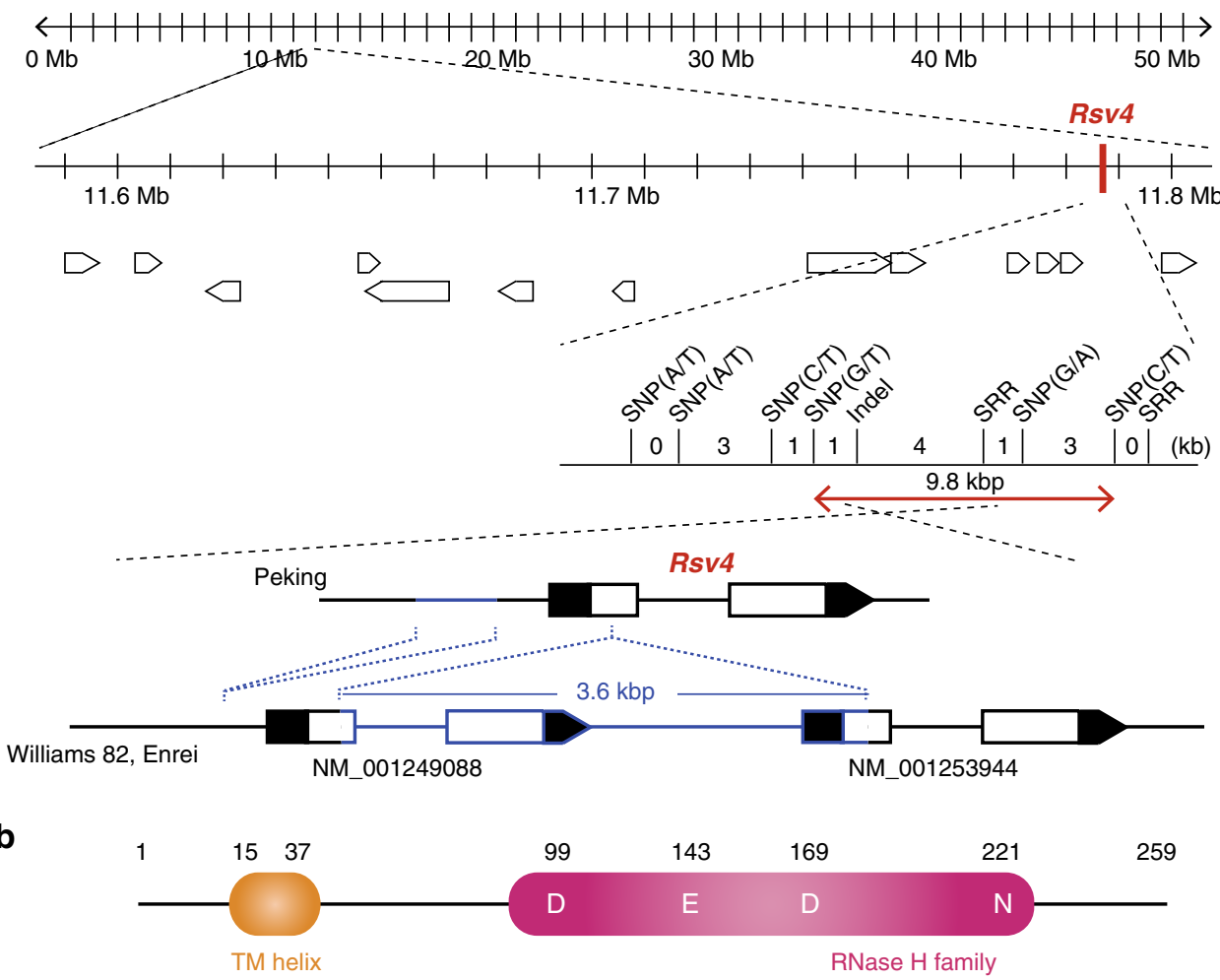

Fig. 1 Positional cloning of Rsv4. a Fine mapping of Rsv4. The gene structures in the Peking, Williams 82, and Enrei genomes are shown at the bottom. Indels are indicated in blue. Black boxes are untranslated regions. b Predicted Rsv4 protein structure. Amino acid positions of the transmembrane (TM) helix and active-site residues of the RNase $\mathrm{H}$ family domain are shown

DNA-RNA hybrid, but it showed manganese-dependent dsRNase activity (Fig. 4a). Magnesium ion did not activate the dsRNase activity of Rsv4 even at $10 \mathrm{mM}$. Thus, Rsv4 is a member of the RNase $\mathrm{H}$ family that degrades only dsRNA. The D99N mutation abolished dsRNase activity (Fig. 4a), suggesting that this activity is essential for SMV resistance. Positive-strand RNA viruses replicate their genomes via a complementary (negativestrand) RNA, which leads to the formation of dsRNA. Thus, a plausible mechanism of action of Rsv4 is to degrade viral dsRNA formed during replication.

Positive-strand RNA viruses replicate their genomes in a membranous replication compartment that is isolated from the cytoplasm $^{26,27}$. Viruses thereby hide their dsRNA replicative intermediates from cytoplasmic surveillance mechanisms. Thus, Rsv4 must somehow enter the site of SMV RNA replication to be able to efficiently inhibit the replication of the virus by degrading viral dsRNA. To test this possibility, we examined whether Rsv4 physically associates with the SMV replication machinery. Since SMV-L(Q1033K) has an amino acid substitution in the P3 protein $^{22,28-30}$, we first examined the interaction of Rsv4 with P3. Currently, the function of $\mathrm{P} 3$ protein of potyviruses remains obscure; however, it has transmembrane regions and interacts with viral NIb polymerase $\mathrm{e}^{31,32}$, and it is suggested to be an essential component of the viral replication complex ${ }^{33}$. When Myc-tagged SMV P3 protein was co-expressed with FLAG-tagged Rsv4 protein in $N$. benthamiana leaves, P3-Myc was coimmunoprecipitated with Rsv4-FLAG from detergentsolubilized membranes of the leaf extracts (Fig. 4b). The tagged Rsv4(D99N) mutant protein (D99N-FLAG) retained the ability to bind P3-Myc (Fig. 4b), indicating that binding ability is not sufficient for resistance. We did not observe any difference between Myc-fused P3 proteins of SMV-C (wild-type) and SMV-
$\mathrm{L}(\mathrm{Q} 1033 \mathrm{~K})$ in their ability to bind Rsv4-FLAG in the immunoprecipitation experiment (Fig. 4c). This is consistent with the above result that Rsv4 could inhibit SMV-L(Q1033K) multiplication when expressed at high levels (Fig. 2f).

Since D99N-FLAG interacted with P3 but did not inhibit SMV multiplication, we speculated that the Rsv4(D99N) mutant protein associates with the viral replication complex without affecting viral replication. We thus further examined whether a viral RdRp is co-purified with D99N-FLAG from solubilized membranes of SMV-infected leaves. Before solubilization, RdRp activity was detected in membrane fractions of D99NFLAG-expressing and GUS (negative control)-expressing leaves inoculated with SMV, but not in those of SMV-inoculated Rsv4FLAG-expressing or non-inoculated GUS-expressing leaves (Fig. 4d). After solubilization and immunoprecipitation with anti-FLAG antibody, RdRp activity was detected in the D99NFLAG-immunoprecipitated fraction (Fig. 4d). SMV NIb protein (the catalytic subunit of RdRp) and P3 protein were detected in the D99N-FLAG-immunoprecipitated fraction. Thus, D99NFLAG physically associates with a replication-catalyzing viral protein complex. These results strongly suggest that in Rsv4expressing cells, Rsv4 enters membrane-surrounded viral replication compartments through its interaction with replication machinery; in the replication compartments, it degrades viral dsRNA replication intermediates. The results also suggest that an active potyviral RdRp contains $\mathrm{P} 3$ protein in addition to the NIb protein.

Rsv4 confers broad-spectrum resistance against potyviruses. The genus Potyvirus consists of over 150 species, accounting for $\sim 15 \%$ of all named plant virus species, and includes many 
a

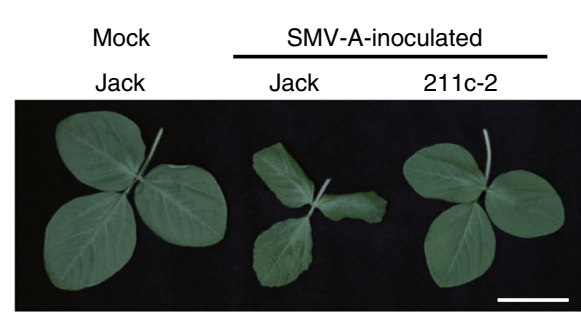

b

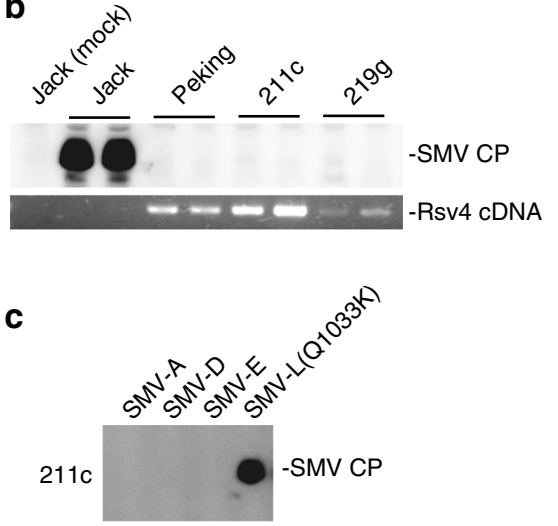

e

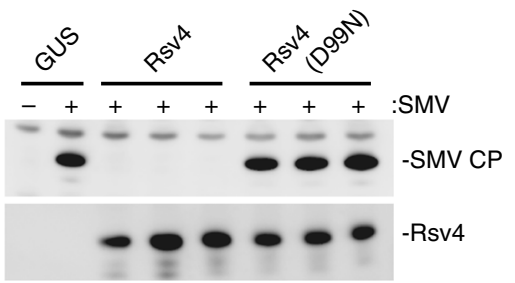

d

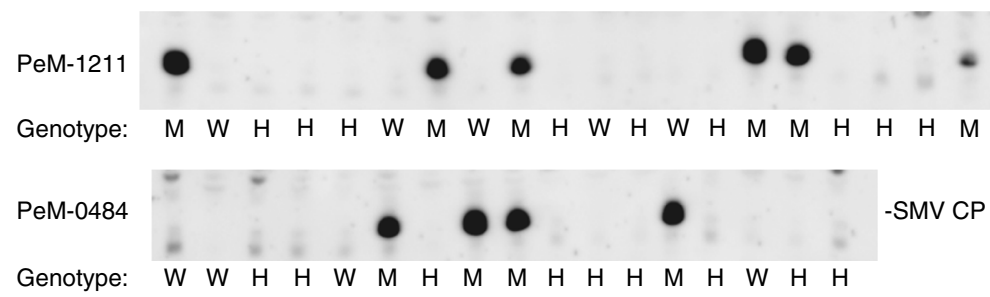

$-S M V$ CP

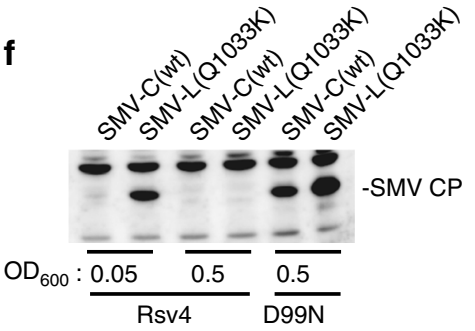

Fig. 2 Rsv4 encodes an RNase H family protein. a Symptoms of SMV-inoculated soybean plants. 211c-2 is a transgenic line derived from susceptible cv. Jack, overexpressing Rsv4 from Peking. Bar $=5 \mathrm{~cm}$. b SMV coat protein (CP) accumulation in control and transgenic soybean plants. 211c expresses Rsv4 cDNA driven by the cauliflower mosaic virus $35 \mathrm{~S}$ promoter, while $219 \mathrm{~g}$ carries a genomic DNA fragment of Peking containing the putative native promoter of Rsv4. SMV CP accumulation in non-inoculated upper leaves was detected by western blotting at 10 days post-inoculation (dpi) (upper panel). Rsv4 mRNA was detected by RT-PCR (lower panel). Lanes represent individual plants. c SMV strains SMV-A, -D, -E, and -L(Q1033K) were used to inoculate 211c, and CP accumulation was analyzed as in panel b. d Co-segregation of PeM-1211 and PeM-0484 (identical nonsense mutations in Peking Rsv4 gene) and SMV-susceptible phenotype. W wild-type, M mutant-type, $\mathrm{H}$ heterozygous. e Rsv4, but not the Rsv4(D99N) mutant protein, inhibits SMV multiplication in N. benthamiana leaves. SMV CP accumulation was detected by western blotting at 5 dpi. $\mathbf{f}$ SMV-L(Q1033K) is less sensitive to Rsv4 than SMV-C. Agrobacterium strains containing constructs to express Rsv4 or Rsv4(D99N) were infiltrated at the indicated concentrations. 1 day after infiltration, Agrobacterium harboring SMV cDNA was infiltrated at $\mathrm{OD}_{600}=0.005$. CP accumulation was detected at $7 \mathrm{dpi}$. The source data of Fig. $2 \mathrm{~b}-\mathrm{f}$ are provided as a Source Data file

Cultivated soybean (Glycine max)

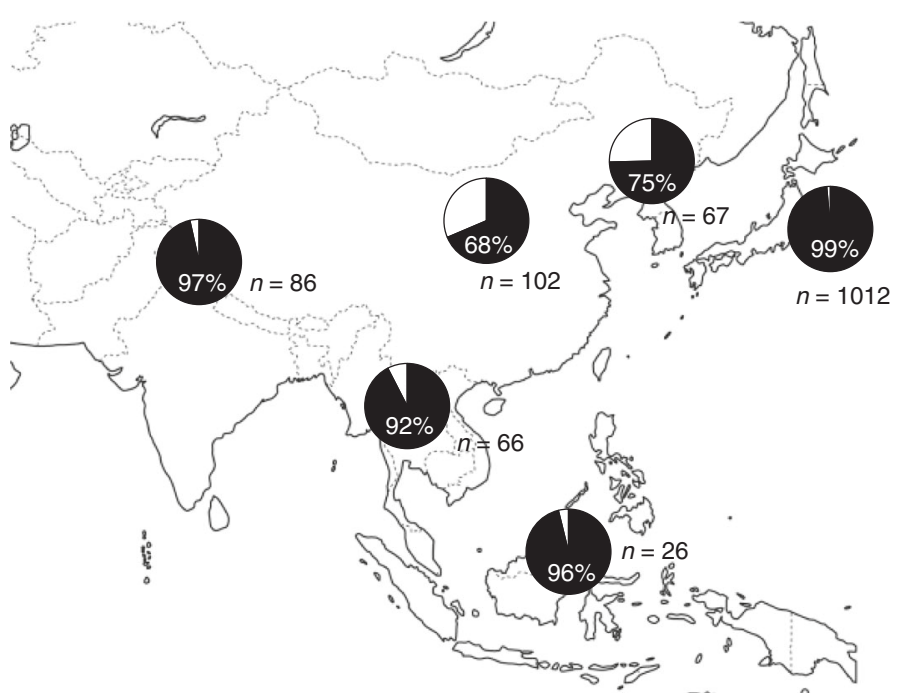

Wild soybean (Glycine soja)

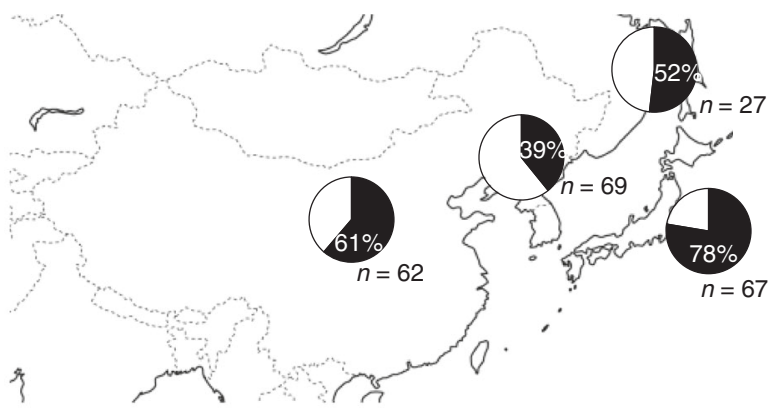

Enrei-, Williams 82-type (having the 3.6-kbp region)

Peking-type (lacking the 3.6-kbp region)

Fig. 3 Geographical distribution of genetic diversity of the Rsv4 locus. The presence or absence of the 3.6-kbp region in Rsv4 in cultivated soybean (Glycine max) and wild soybean (G. soja) are shown in black or white, respectively. The number of investigated plants and percentage of plants having the 3.6-kbp region are indicated for each geographical area. See also Supplementary Data 1 
a

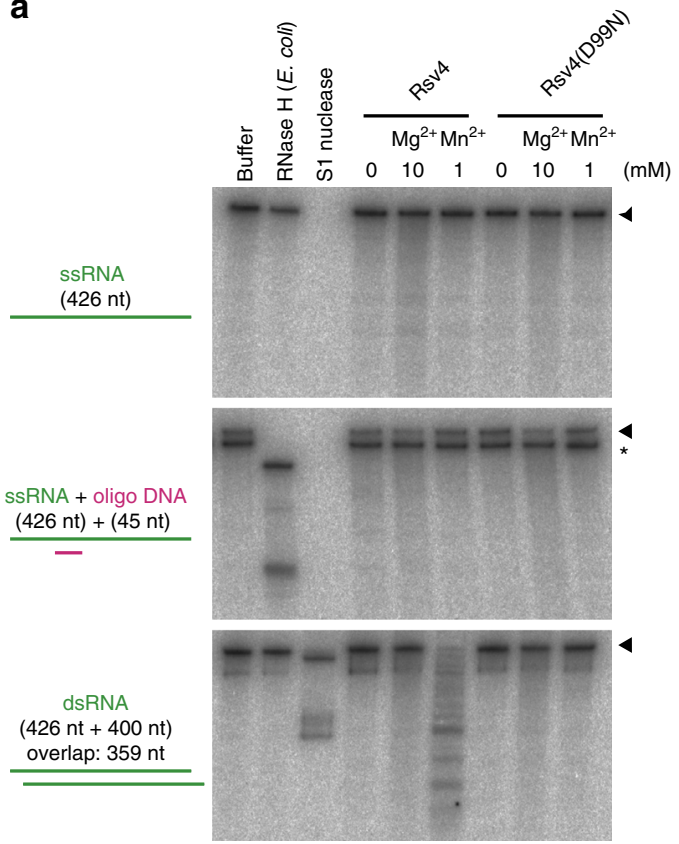

b

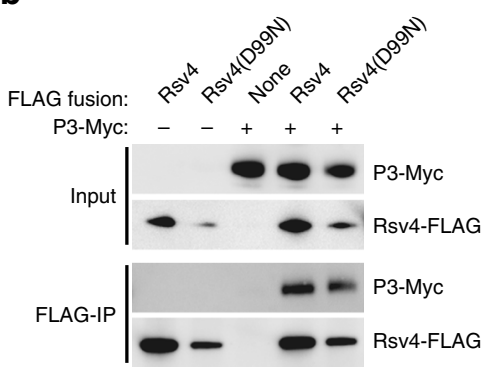

c

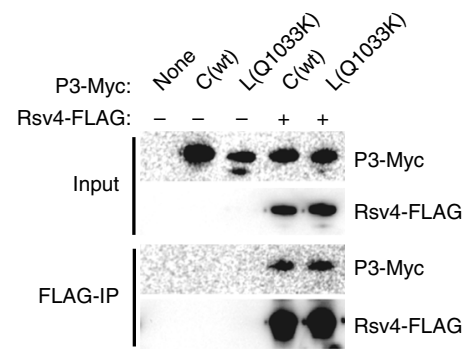

d

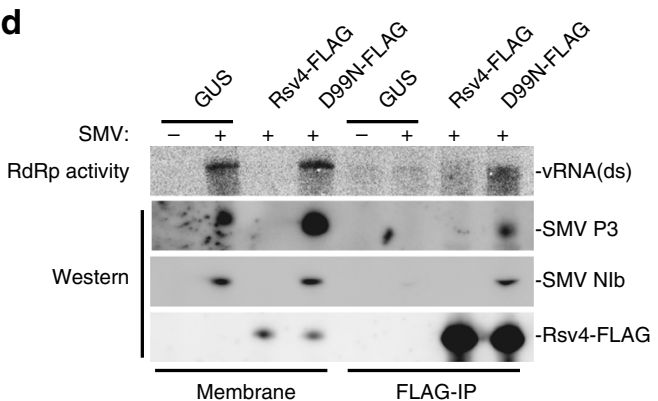

Fig. 4 Rsv4 is a Mn²+-dependent dsRNase that associates with SMV replication machinery. a Activity of Rsv4. Purified Rsv4 protein or Rsv4 with a D99N substitution was incubated with ${ }^{32}$ P-labeled ssRNA (top), ssRNA hybridized with oligo DNA (middle), or dsRNA (bottom). Divalent cation was supplied as indicated. As controls, E. coli RNase H and S1 nuclease were used. RNA was detected by urea-PAGE followed by autoradiography. Positions of the substrate RNAs are indicated to the right by arrowheads. The bands marked by an asterisk migrated at the same speed as the ssRNA. b SMV P3-Myc is coimmunoprecipitated with Rsv4-FLAG. Proteins were detected by anti-FLAG and anti-Myc antibodies. c P3-Myc from SMV-L(Q1033K) is coimmunoprecipitated with Rsv4-FLAG. C(wt) indicates strain SMV-C. d Rsv4(D99N) associates with SMV RdRp in infected leaves. Membrane fractions of leaf homogenates (Membrane) and immunoprecipitates using anti-FLAG antibody after solubilization (FLAG-IP) were analyzed by ${ }^{32} \mathrm{P}$ incorporation (RdRp activity) and western blotting (P3 and NIb). The source data of Fig. 4a-d are provided as a Source Data file

agriculturally important viruses worldwide ${ }^{34}$. We tested whether Rsv4 inhibits multiplication of other potyviruses by using agroinfiltration-mediated transient expression in N. benthamiana. Remarkably, multiplication of TuMV, PVY, PPV, bean common mosaic virus (BCMV), potato virus A (PVA), and peanut mottle virus (PeMoV) was inhibited by Rsv4 (Fig. 5a). TuMV causes severe symptoms in $N$. benthamiana but did not induce any symptoms when inoculated onto Rsv4-expressing leaves (Fig. 5b). Thus, Rsv4 can confer broad-spectrum resistance against potyviruses. Accumulated levels of the genomic RNA of tomato mosaic virus (ToMV; genus Tobamovirus, family Virgaviridae), a positive-strand RNA virus, were comparable in the presence of Rsv4 and Rsv4(D99N) (Fig. 5a). This result disproves the possibility that Rsv4 nonspecifically degrades dsRNAs of all positive-strand RNA viruses, and provides further evidence for the importance of the interaction of Rsv4 with potyvirus replication machinery for resistance.

Engineering dsRNases targeting viral replication sites. Virtually all eukaryotic positive-strand RNA viruses replicate in membrane-bound replication complexes, and the dsRNA replication intermediates are formed only within the membrane compartments. The model for Rsv4 action we describe here suggests that dsRNase can confer resistance against any positivestrand RNA virus if the enzyme is delivered into the replication compartment (Fig. 6a). To examine this antiviral activity, we fused a dsRNase protein, RTL2 ${ }^{35}$ from Arabidopsis thaliana (chosen because RTL2 does not have a transmembrane region), with three host proteins, each of which has been proposed to be associated with the replication complex of a specific virus: TOM1 for ToMV ${ }^{36}$, TIP1 for cucumber mosaic virus $(\mathrm{CMV})^{37}$, and eIF (iso) $4 \mathrm{E}$ for $\mathrm{TuMV}^{38}$ (genus Tobamovirus, Cucumovirus, and
Potyvirus, respectively). When transiently expressed in $N$. benthamiana leaves, these fusion proteins greatly suppressed the multiplication of the corresponding viruses (Fig. 6b). Neither RTL2 itself nor fusion proteins with a catalytic mutation in RTL2 (D100A) inhibited multiplication of the viruses. These results reinforce the validity of the model for the virus resistance mechanism used by Rsv4, i.e., penetration of dsRNases into viral replication compartments, and suggest its applicability to designing resistance genes against viruses of interest.

\section{Discussion}

In the present study, we identified the broad-spectrum SMV resistance gene Rsv4 of soybean by positional cloning and demonstrated its function by transgenic expression in SMVsusceptible soybean, mutagenesis in SMV-resistant soybean, transient expression in $N$. benthamiana, and biochemical analyses. Genomic rearrangements likely caused the $3.6-\mathrm{kbp}$ insertion/deletion in the Rsv4 locus, but it is unclear exactly how the locus evolved. The geographical distribution of the $3.6-\mathrm{kbp}$ insertion/deletion in soybean and Glycine soja shown in Fig. 3 suggests that genetic variation of this chromosome region was reduced during expansion of soybean outside its probable areas of domestication (China and Korea). Tandemly repeated SMVsusceptible Rsv4 alleles with the 3.6-kb region also encode RNase $\mathrm{H}$ proteins with the $\operatorname{DEDD}(\mathrm{N})$ motif (Supplementary Fig. 5), and NM_001249088 (present in susceptible cultivars containing the 3.6-kbp insertion) inhibited SMV multiplication when overexpressed in N. benthamiana (Supplementary Fig. 6a). Thus, it is possible that the SMV-susceptible Rsv4 alleles confer resistance to viruses that are not adapted to soybean, as in the case of $T m-1 / t m-1$ of tomato: a susceptible allele of ToMV 
a

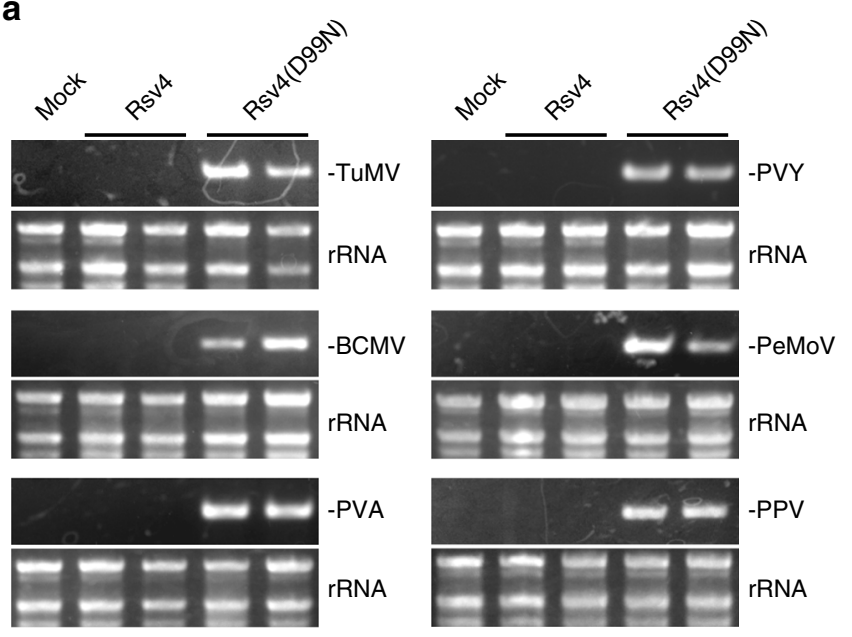

b

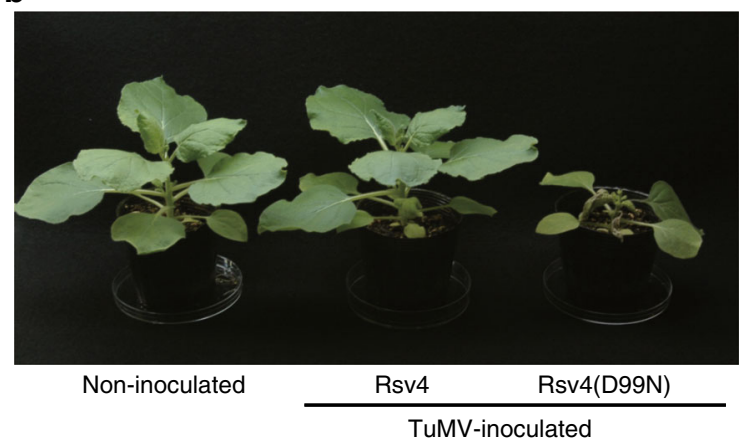

Fig. 5 Rsv4 confers broad-spectrum resistance against potyviruses. a Accumulation of viral RNA in inoculated plants. Turnip mosaic virus (TuMV), potato virus $Y$ (PVY), bean common mosaic virus (BCMV), peanut mottle virus (PeMoV), potato virus $A(P V A)$, plum pox virus (PPV), or tomato mosaic virus (ToMV) were inoculated onto $\mathrm{N}$. benthamiana leaves expressing Rsv4 or Rsv4(D99N), and accumulation of viral RNA in systemic leaves was detected by RT-PCR at 7-14 dpi. rRNAs were used as loading controls. b Symptoms of TuMV-inoculated N. benthamiana expressing Rsv4 or Rsv4(D99N) at 12 dpi. The source data of Fig. $5 a$ are provided as a Source Data file

resistance gene $T m-1$ inhibits multiplication of viruses that are not adapted to tomato ${ }^{39}$.

Most dominant virus resistance genes in plants encode NB-LRR proteins that elicit a defense reaction upon recognition of the corresponding viruses. Several others encode a variety of proteins functionally divided into two groups: inhibitors of viral propagation that target RNA replication ${ }^{40-42}$ or systemic transport ${ }^{43-45}$, and modulators of plant immunity that include an enzyme sulfonating salicylic acid ${ }^{46}$ and RNA-dependent RNA polymerases ${ }^{47,48}$. We found that Rsv4 encodes a dsRNase that associates with the SMV replication machinery. Although sequestering dsRNA is a universal feature of eukaryotic positivestrand RNA viruses and functions as a countermeasure to host antiviral immunity, Rsv4 is able to contact P3 and/or other viral proteins during replication complex assembly and enter the viral replication compartment, where it degrades viral dsRNA formed during replication. a

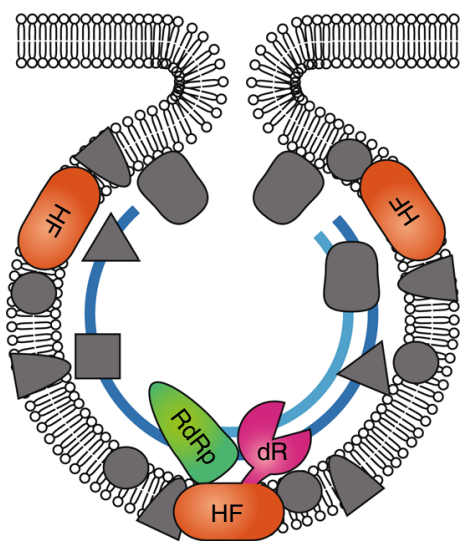

b

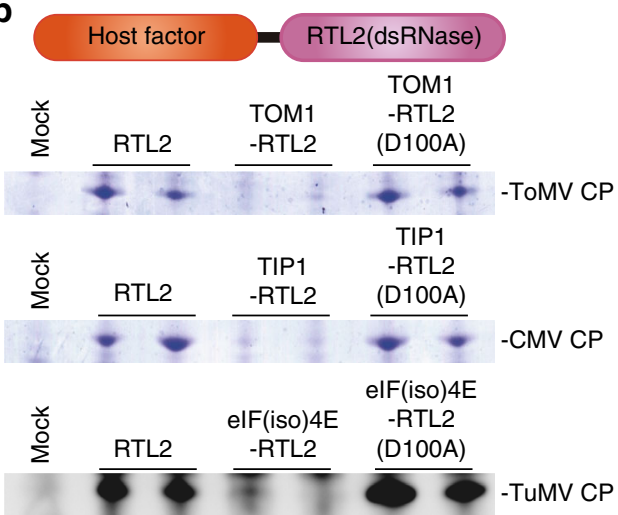

Fig. 6 Targeted inhibition of virus multiplication by dsRNases fused with host factors involved in viral RNA replication. a Working model for targeted inhibition. By fusing a dsRNase (dR) with host factors (HF) included in the viral replication complex, dsRNase is delivered into the replication compartment. $\mathbf{b}$ Inhibition of multiplication of three different viruses by dsRNases designed to target the replication complexes of each virus. Accumulation of coat proteins (CP) in inoculated leaves was examined by Coomassie staining (ToMV and CMV) or western blotting (TuMV) at 2-4 dpi. The RTL2 (D100A) constructs contain a catalytic mutation in RTL2. The source data of Fig. $6 \mathrm{~b}$ are provided as a Source Data file

Rsv4 interacts, whether directly or indirectly, with the SMV P3 protein (Fig. 4b). A key amino acid residue of SMV P3 that is recognized by Rsv4, Q1033, is predicted to reside within the transmembrane region ${ }^{22}$. Thus, Rsv4 and P3 may interact via transmembrane helix-helix interactions. It is possible that even in the presence of Rsv4, SMV makes Rsv4-free replication complexes at a low frequency, enabling viral genomic RNA to be continuously produced. The second-generation genomes could also form functional replication complexes at a low frequency. When progeny SMV genomes move to neighboring uninfected cells, they would again form Rsv4-free replication complexes at a low frequency. We propose that these processes could explain the slow SMV spread observed even in Rsv4 plants ${ }^{18}$. SMV mutants whose P3 proteins have lower affinity to Rsv4 would form Rsv4free replication complexes more frequently than wild-type strains. SMV-L(Q1033K) only partially breaks Rsv4-mediated resistance (Fig. $2 \mathrm{f}$ ), and its $\mathrm{P} 3$ protein still had a detectable affinity to Rsv4 in the immunoprecipitation assay (Fig. 4c). Considering that SMV mutants that show virulence on Rsv4 plants had reduced fitness in susceptible hosts ${ }^{49}$, P3 mutations that abolish affinity to Rsv4 may be deleterious to SMV. Future studies for quantitative measurements of the affinity between Rsv4 and P3, and their derivatives, would provide further support for our model. 
As a complement to traditional breeding, biotechnological engineering has been an alternative approach to producing virusresistant crops. Abel et al. showed that transgenic tobacco plants expressing the coat protein $(\mathrm{CP})$ gene of tobacco mosaic virus are resistant to the virus ${ }^{50}$. This method, referred to as pathogenderived resistance, also includes RNA interference against viral genome sequences ${ }^{51}$. Pathogen-derived resistance has been used to produce many virus-resistant crops $^{52}$; however, only a handful of these transgenic plants having viral genes have been commercialized because of problems including a lack of regulatory framework in developing countries ${ }^{53}$. Another way to engineer virus-resistant crops is knockout/knockdown of host genes that are essential for virus multiplication ${ }^{54}$. This strategy does not need transgenic techniques when the knockout/knockdown is achieved using mutagenesis or genome editing, but few examples are available since loss of function of host factor genes most often affects plant growth.

We could successfully imitate Rsv4 to design custom-made antiviral proteins by fusion of a dsRNase with host proteins used by viruses for their replication. In contrast to the genetically modified virus-resistant crops created by introduction of viral genes, dsRNase-mediated resistance only requires a fusion of endogenous host genes. Thus, using this method in combination with a knock-in technology, it may be possible to create transgene-free virus-resistant crops. The resultant virus-resistant plants would grow normally if the original functions of the host factors are unaffected by fusion with dsRNase. Although transient expression of the dsRNase-host factor fusion proteins did not completely inhibit multiplication of the target viruses (Fig. 6b), knock-in plants would be expected to show higher resistance because the endogenous dsRNase-free host factors would no longer be available for the viruses. An additional advantage of this method is that plants resistant to multiple viruses may be produced by fusing dsRNase to factors commonly used by diverse viruses.

\section{Methods}

Plant materials. A genetic mapping population for Rsv4 was developed from a cross between SMV-C-resistant cultivar 'Peking' (Rsv4) and SMV-C-susceptible cultivar 'Enrei' ( $r s v 4)$. Both soybeans were obtained from Nagano Vegetable and Ornamental Crops Experiment Station, Shiojiri, Japan, and registered as accession numbers GmWMC084 (Peking) and GmJMC025 (Enrei) in the NIAS soybean mini core collection of the Genetic Resources Center, NARO, Tsukuba, Japan. An $\mathrm{F}_{2}$ mapping population consisting of 190 plants was initially used to delimit the Rsv4 locus by using simple sequence repeat (SSR) markers. For fine mapping, five backcross populations consisting of 9320 individuals in total were further developed from $\mathrm{F}_{1}$ plants between 'Enrei' and 'Peking' using 'Enrei' as a female recurrent parent in the cross to obtain materials having recombination around Rsv4 (Supplementary Fig. 1). Seeds with recombination detected by marker analysis were selectively grown to obtain progenies in the field or vinyl greenhouse at the Institute of Crop Sciences, Tsukuba, Japan $\left(36^{\circ} 2^{\prime} \mathrm{N}, 140^{\circ} 8^{\prime} \mathrm{E}\right)$, from June to November. The progenies of the recombinants were used to examine resistance to SMV.

A total of 1383 cultivated (Glycine max [L.] Merr.) and 261 wild (G. soja Sieb. \& Zucc.) soybean accessions from the Genetic Resources Center, NARO, in Japan and the United States Department of Agriculture (USDA) were used for diversity analyses (Supplementary Data 1). The detailed genetic relationship of the materials was reported by Kaga et al. ${ }^{55}$. Twenty-nine additional accessions known to have $R s v 4^{18,56}$ or derived from collection with a name 'Peking' were obtained from USDA.

Viruses. The following viruses were obtained from the Genetic Resources Center, NARO: SMV-A (MAFF 104063), SMV-C (104065), SMV-D (104066), SMV-E (104067), TuMV (715062), PVY (307024), BCMV (715049), PVA (307028), and PeMoV (307044). PPV was a generous gift from Drs. S. Namba, Y. Yamaji, and K. Maejima (University of Tokyo). Full-length SMV-L(Q1033K) cDNA was synthesized according to the deposited nucleotide sequence (EU871724) for construction of the infectious clone.

Fine mapping of Rsv4. Publicly available SSR markers (Supplementary Data 2) were initially used to construct a linkage map around Rsv4 using the $\mathrm{F}_{2}$ population as described above. Based on these results, 25 SSR markers were designed to SSR core motifs around Rsv 4 by using Primer3 with default parameters ${ }^{57}$ based on the reference sequence of soybean chromosomes (cultivar Williams 82, version Gmax_18958) obtained from the Phytozome FTP site (https://phytozome.jgi.doe. gov/pz/portal.html). To ensure specificity, primer sequences were searched agains Gmax_189 to examine the number of potential binding sites, amplicon size, and location by using Genome Tester ${ }^{59}$ with default parameters. Total genomic DNA was extracted from young fresh leaves $(0.3 \mathrm{~g})$ or seed powder $(50 \mathrm{mg})$ by using guanidine hydrochloride and proteinase $\mathrm{K}$ according to Khosla et al. ${ }^{60}$ with several modifications. Primers fluorescently labeled with three kinds of dye (6-FAM, HEX, and NED) were used to analyze SSR markers. Multiplex PCR consisting of several markers with different dyes was performed using a QIAGEN Multiplex PCR Kit (QIAGEN). PCR mixtures $(5 \mu \mathrm{l})$ contained $0.2 \mu \mathrm{l}$ of template DNA (50 ng per $\mu \mathrm{l}$ ), $2.5 \mu \mathrm{l}$ of $2 \times$ Multiplex PCR Mix, $1 \mu \mathrm{l}$ of $5 \times \mathrm{Q}$ solution, and $0.1 \mu \mathrm{l}$ of $10 \mu \mathrm{M}$ each primer. Touchdown PCR was programmed on a GeneAmp 9700 (Applied Biosystems) as follows: 1 cycle of initial denaturation at $95^{\circ} \mathrm{C}$ for $15 \mathrm{~min} ; 3$ cycles of $94^{\circ} \mathrm{C}$ for $30 \mathrm{~s}$ and $68^{\circ} \mathrm{C}$ for $3 \mathrm{~min} ; 3$ cycles of $94^{\circ} \mathrm{C}$ for $30 \mathrm{~s}$ and $66^{\circ} \mathrm{C}$ for $3 \mathrm{~min} ; 3$ cycles of $94{ }^{\circ} \mathrm{C}$ for $30 \mathrm{~s}$ and $64^{\circ} \mathrm{C}$ for $3 \mathrm{~min} ; 3$ cycles of $94^{\circ} \mathrm{C}$ for $30 \mathrm{~s}, 62^{\circ} \mathrm{C}$ for 3 min, and $1 \mathrm{~min}$ at $72^{\circ} \mathrm{C} ; 3$ cycles of $94^{\circ} \mathrm{C}$ for $30 \mathrm{~s}, 60^{\circ} \mathrm{C}$ for $3 \mathrm{~min}$, and $1 \mathrm{~min}$ at $72^{\circ}$ $\mathrm{C} ; 3$ cycles of $94^{\circ} \mathrm{C}$ for $30 \mathrm{~s}, 58^{\circ} \mathrm{C}$ for $3 \mathrm{~min}$, and $1 \mathrm{~min}$ at $72^{\circ} \mathrm{C} ; 40$ cycles of $30 \mathrm{~s}$ at $94^{\circ} \mathrm{C}, 3 \mathrm{~min}$ at $55^{\circ} \mathrm{C}$, and $1 \mathrm{~min}$ at $72{ }^{\circ} \mathrm{C}$; and final extension for $10 \mathrm{~min}$ at $72^{\circ} \mathrm{C}$. The PCR product was diluted $1 / 10$ with water, and $1 \mu \mathrm{l}$ was denatured in $10 \mu \mathrm{l}$ of Hi-Di formamide with $0.2 \mu \mathrm{l}$ of GeneScan 400HD ROX size standard and separated on an ABI 3730 capillary sequencer (Applied Biosystems). SSR marker genotypes were determined by using ABI GeneMapper ver.4.0 software (Applied Biosystems) The linkage map of Rsv4 was constructed in JoinMap ver.4.0 $0^{61}$ and the marker order of the $\mathrm{F}_{2}$ linkage map was determined using the maximum-likelihood mapping algorithm. The recombination frequency was converted into genetic distance (cM) using the Haldane mapping function. In addition, the linkage between the genotypes of two SSR markers, Rsv4_446 and Rsv4_320 (Supplementary Data 2), and the SMV-C resistance phenotype was examined among $68 \mathrm{~F}_{2}$ progenies between Tosan 155 (derived from a cross between Fukusennari and Enrei) and Enrei to test whether the SMV-C resistance of Fukusennari maps to the Rsv4 region.

For fine mapping, the genotypes of markers Rsv4_446 and Rsv4_320 were screened to obtain recombinants in the Rsv4 region in the backcross populations. Single-nucleotide polymorphisms (SNPs) were genotyped for the recombinants by the direct-sequencing method. Primer pairs were designed around the SNPs to amplify 600-1000-bp fragments based on the procedure described above. These primer pairs are listed as Rsv4-s04-07_1, Rsv4-s035-6_71, Rsv4-86105snp_42, Rsv4-RC-1_93, and Rsv4-RC-3_55 in Supplementary Data 2. Reaction mixtures consisted of $5 \mu \mathrm{l}$ of $2 \times \mathrm{GoTaq}^{\circledR}$ Colorless Master Mix (Promega, Madison, WI, USA), $0.2 \mu \mathrm{l}$ of $10 \mu \mathrm{M}$ each forward and reverse primers, and $0.2 \mu \mathrm{l}$ of the template DNA in a total volume of $10 \mu \mathrm{l}$. The PCR was performed as follows: 1 cycle of initial denaturation at $95^{\circ} \mathrm{C}$ for $2 \mathrm{~min} ; 40$ cycles of denaturation for $15 \mathrm{~s}$ at $95^{\circ} \mathrm{C}$, annealing for $30 \mathrm{~s}$ at $53^{\circ} \mathrm{C}$, and extension for $1.5 \mathrm{~min}$ at $60^{\circ} \mathrm{C}$. The PCR products were cleaned with ExoSAP-IT (USB Corporation, Cleveland, OH, USA). Sequencing was performed with an ABI Prism BigDye Terminator v 3.1 cycle sequencing kit (Applied Biosystems) and $5 \mathrm{pmol}$ of one of the primers used to amplify the PCR product on an ABI 3730xl automated DNA analyzer (Applied Biosystems) according to the manufacturer's manual. The sequence

chromatograms were aligned with the reference sequence to determine genotypes with Sequencher 5.2 (Gene Codes Corporation, Ann Arbor, MI, USA).

Two sequence-tagged site (STS) markers, detected by the Rsv4-Seq03 and Rsv4Seq04 primer pairs (Supplementary Data 2), were designed to amplify 6-kbp and $6.3-\mathrm{kbp}$ regions, respectively, near $R s v 4$. PCR mixtures $(10 \mu \mathrm{l})$ contained $0.2 \mu \mathrm{l}$ of template DNA ( $50 \mathrm{ng}$ per $\mu \mathrm{l}$ ), $2 \mu \mathrm{l}$ of $5 \times$ PrimeSTAR GXL Buffer (Takara Bio, Shiga, Japan), $1.0 \mu \mathrm{l}$ of PrimeSTAR GXL DNA Polymerase (1.25 U per $\mu \mathrm{l}), 0.8 \mu \mathrm{l}$ of $2.5 \mathrm{mM}$ dNTPs, and $0.1 \mu \mathrm{l}$ of $20 \mu \mathrm{M}$ each forward and reverse primers. PCR was performed on a GeneAmp PCR System 9700 (Applied Biosystems) with the following program: initial denaturation for $5 \mathrm{~s}$ at $98^{\circ} \mathrm{C}$; 35 cycles of denaturation for $10 \mathrm{~s}$ at $98^{\circ} \mathrm{C}$, annealing and extension for $30 \mathrm{~s}$ at $68^{\circ} \mathrm{C}$; and final extension for $30 \mathrm{~s}$ at $68^{\circ} \mathrm{C}$. Genotypes for the two STS markers were visually classified based on fragment size by $1 \%$ agarose gel electrophoresis: $2.5 \mathrm{kbp}$ (Peking type) and $6 \mathrm{kbp}$ (Enrei type) for Rsv4-Seq03; $10 \mathrm{kbp}$ (Peking type) and $6.3 \mathrm{kbp}$ (Enrei type) for Rsv4-Seq04.

Virus inoculation and detection. SMV-C and SMV-L(Q1033K) cDNAs were cloned into pBI121 for agroinfection into N. benthamiana leaves. For inoculation of soybean plants, viruses were propagated in soybean cultivar 'Tsuruno Tamagol' (SMV-C, D, and E) or 'Jack' (SMV-A, C, and E). Each inoculum was prepared from $1 \mathrm{~g}$ of infected leaf tissue, which was homogenized in $10 \mathrm{ml}$ of $0.1 \mathrm{M}$ sodium phosphate buffer, $\mathrm{pH} 7.0$, by using a mortar and pestle. Inoculation was performed before the trifoliate leaves emerged. Unifoliate soybean leaves were dusted with carborundum before inoculation, then rubbed softly with a cotton puff to distribute the inoculum, and finally rinsed with tap water. Inoculated plants were grown in a greenhouse at 18 to $25^{\circ} \mathrm{C}$ for 2 to 3 weeks and classified into three phenotype classes based on symptoms of 15 to 30 plants per line: resistant (all plants were symptomless), susceptible (more than $80 \%$ of plants had mosaic symptoms), and segregating (about $25 \%$ of plants had mosaic symptoms). Additional plants were 
inoculated to confirm phenotype classifications when necessary. Inoculation of potyviruses other than SMV into $N$. benthamiana leaves was performed mechanically using homogenates of infected leaves as described above. Anti-SMVCP rabbit antiserum was raised against an E. coli-expressed SMV-C CP. For quantification of SMV accumulation, the SMV CP bands of Western blotting were measured by Image ${ }^{62}$. Anti-SMV-P3 and -NIb rabbit antisera were raised against synthetic peptides CFPVAVSMTGQSEDVSAQ and CVGA-

QYKGKKQDYFSGMD, respectively. Anti-TuMV-CP antiserum was purchased from the Japan Plant Protection Association (Tokyo, Japan). All antisera used for Western blotting were diluted at 1:1000 in TBST containing 5\% (w/v) skim milk. Primers used for detection of viral RNA by RT-PCR are listed in Supplementary Data 2.

Sequencing analysis of the Rsv4 region. Long-range PCR was conducted to amplify a 16-kbp genomic fragment including the delimited 9.8-kbp fragment of the Rsv4 region from 'Peking' using primer pair rsv4L15_L_4957 (Supplementary Data 2). PCR mixtures ( $10 \mu \mathrm{l}$ ) contained $0.2 \mu \mathrm{l}$ of template DNA (50 ng per $\mu \mathrm{l}), 2 \mu \mathrm{l}$ of $5 \times$ PrimeSTAR GXL Buffer (Takara Bio), $0.2 \mu$ of PrimeSTAR GXL DNA Polymerase (1.25 U per $\mu \mathrm{l}), 0.8 \mu \mathrm{l}$ of $2.5 \mathrm{mM}$ dNTPs, and $0.1 \mu \mathrm{l}$ of $20 \mu \mathrm{M}$ each forward and reverse primers. PCR was performed on a GeneAmp PCR System 9700 (Applied Biosystems) with the following program: initial denaturation for $5 \mathrm{~s}$ at $98^{\circ} \mathrm{C} ; 30$ cycles of denaturation for $10 \mathrm{~s}$ at $98^{\circ} \mathrm{C}$, annealing and extension for $7 \mathrm{~min} 50 \mathrm{~s}$ at $68^{\circ} \mathrm{C}$; and final extension for $30 \mathrm{~s}$ at $68^{\circ} \mathrm{C}$. The sequence of the 16 $\mathrm{kbp}$ fragment was determined by the construction of random transposon insertion clones according to the protocol supplied with the EZ-Tn $5^{\mathrm{m}}<\mathrm{KAN}-2>$ Insertion Kit (Epicentre). Sequencing was performed with an ABI Prism BigDye Terminator v 3.1 cycle sequencing kit (Applied Biosystems) and 5 pmol of the sequencing primers provided with the EZ-Tn5 ${ }^{\mathrm{mm}}$ kit on an ABI-3730xl automated DNA analyzer (Applied Biosystems) according to the manufacturer's manual. The bidirectional sequence chromatograms generated from the 470 clones were assembled into a 16,159-bp contig using Sequencher 5.2.

RNA analysis. Total RNA was isolated from young trifoliate leaves by using an RNeasy ${ }^{\oplus}$ Plant Mini Kit following the on-column DNase protocol (QIAGEN). RT-PCR was conducted by using a PrimeScript One Step RT-PCR Kit (Takara Bio) and the primer pair ORF2 (Supplementary Data 2), designed to the presumed Rsv4 ORFs. PCR was performed on a GeneAmp PCR System 9700 (Applied Biosystems) with the following program: initial denaturation for $5 \mathrm{~s}$ at $98^{\circ} \mathrm{C} ; 30 \mathrm{cycles}$ of denaturation for $10 \mathrm{~s}$ at $98^{\circ} \mathrm{C}$, annealing and extension for $7 \mathrm{~min} 50 \mathrm{~s}$ at $68^{\circ} \mathrm{C}$; and final extension for $30 \mathrm{~s}$ at $68^{\circ} \mathrm{C}$. mRNA was purified from total RNA using a MagExtractor ${ }^{\text {rix }}$ kit (TOYOBO, Japan). Full-length cDNA sequence was obtained by using a GeneRacer ${ }^{\mathrm{rt}}$ Kit (Invitrogen) and nested primer sets for 5' amplification (rsv4-5-1 and rsv4-5-2) or 3' amplification (rsv4-3-1 and rsv4-3-2; Supplementary Data 2) according to the manufacturer's manual.

Transformation of soybean plants with Rsv4. The Rsv4 RT-PCR product amplified by primer pair ORF2 was re-amplified using an adaptor primer pair, OEatg-1 and OEtga-1 (Supplementary Data 2). The fragment was double-digested by restriction enzymes SpeI and XhoI and cloned into the SacI-XbaI sites of the pMDC123-GFP vector ${ }^{63}$. Then, a fragment containing the cauliflower mosaic virus (CaMV) $35 \mathrm{~S}$ promoter, Rsv $4 \mathrm{cDNA}$, and the NOS terminator of Agrobacterium tumefaciens was amplified using the primer pair P35SF1spe and TNOSR1xho (Supplementary Data 2), and the DNA fragment was double-digested by SpeI and XhoI and cloned into the SpeI-XhoI sites of the pUHR SK plasmid vector.

The genomic DNA construct for transformation was obtained as follows. PCR mixtures $(50 \mu \mathrm{l})$ contained $2 \mu \mathrm{l}$ of template DNA (50 ng per $\mu \mathrm{l}), 10 \mu \mathrm{l}$ of $5 \times$ PrimeSTAR HS Buffer (Takara Bio), $1 \mu$ of PrimeSTAR HS DNA Polymerase ( $2.5 \mathrm{U}$ per $\mu \mathrm{l}$ ), $4 \mu \mathrm{l}$ of $2.5 \mathrm{mM}$ dNTPs, and $2.5 \mu \mathrm{l}$ of $20 \mu \mathrm{M}$ Rsv4-Seq04 primer pair (Supplementary Data 2). PCR was programmed as follows: initial denaturation for $2 \mathrm{~s}$ at $98^{\circ} \mathrm{C} ; 30$ cycles of denaturation for $10 \mathrm{~s}$ at $98^{\circ} \mathrm{C}$, annealing and extension for $5 \mathrm{~min}$ at $68^{\circ} \mathrm{C}$; and final extension for $10 \mathrm{~s}$ at $68^{\circ} \mathrm{C}$. The DNA fragment was double-digested by restriction enzymes SpeI and HindIII and cloned into the SpeIHindIII sites of the pUHR SK plasmid vector. The sequences of several clones were confirmed in advance of transformation.

The construct was introduced by biolistic transformation into cultured cells derived from immature embryos of the SMV-susceptible cultivar 'Jack' as described by Nishizawa et al. ${ }^{64}$. T0 plants derived from hygromycin-resistant and redfluorescent embryogenic cells were grown at $28^{\circ} \mathrm{C}$ day $/ 23^{\circ} \mathrm{C}$ night in a temperature-controlled glasshouse. Genomic DNA from regenerated T0 plants and T1 plants was used to confirm transformation by the constructs. Two primer pairs, pDsRed2_135 and hpt (Supplementary Data 2), were used to amplify the DsRed and HPT genes, respectively. In addition, RT-PCR for total RNA from young leaves was conducted to confirm expression of Rsv4 in each T1 and T2 plant by using the primer pair ORF2 (Supplementary Data 2).

Long-range PCR was performed to identify germplasm with a 3.6-kbp deletion (as found in the Peking genome) using the primer pair Rsv4-Seq03 as described above. Based on the fragment sizes, germplasm was classified for the absence (PCR product size is $2.5 \mathrm{kbp}$ ) or presence ( $6 \mathrm{kbp}$ ) of the $3.6-\mathrm{kbp}$ fragment by $1 \%$ agarose gel electrophoresis.
Isolation of Peking Rsv4 mutants. A mutant library was developed for Peking, and Rsv4 mutants were identified as in Tsuda et al. ${ }^{65}$. Briefly, seeds of Peking were treated with the chemical mutagen EMS, and M2 seeds produced by M1 plants were treated with EMS once again to increase the mutation density. The resultant mutant library, which consisted of DNA and seeds from 1536 M2 plants, was screened by using indexed amplicon sequencing to retrieve Rsv4 mutants. The primer pair Gm02-Rsv4-1n-5000_F and Gm02-Rsv4-1n-5001_R (Supplementary Data 2) was used to amplify a 3.6 -kbp region covering Rsv4 using the long-range PCR method described above and used for indexed amplicon sequencing. Only base changes leading to stop codon or amino acid substitutions observed in more than $2 \%$ of the aligned amplicon reads on the 3.6-kbp Peking Rsv4 sequence were selected to isolate mutants from the library by direct sequencing using the primer pair ORF2 (Supplementary Data 2). After identification of mutants, genotypes of their progenies were confirmed by the same procedure.

Transient expression in $\mathbf{N}$. benthamiana. Rsv4 cDNA was cloned into pMLH713366. The D99N mutant was created by changing the $99^{\text {th }}$ codon, for aspartic acid (GAT), to that for asparagine (AAT). Rsv4-FLAG and D99N-FLAG were created by inserting 5'-GGAGGTGGAGATTATAAGGATGATGATGATA AG-3' before the stop codon of the respective Rsv4 gene. P3-Myc was created by inserting the SMV-C cDNA sequence encoding the Gly766 to Gln1112 residues of the polyprotein between the initiation codon (ATG) and the Myc-tag coding sequence (5'-GGAAGATCTGAGCAGAAGCTTATTTCTGAGGAGGATCTTT GAGCTC-3') and cloned into pMLH7133. A synthetic p19 gene of tomato bushy stunt virus was cloned into pRI101-AN (TaKaRa Bio). Unless otherwise noted, a mixture of Agrobacterium strains that express the proteins of interest and p19 was infiltrated into $N$. benthamiana leaves using a needleless syringe at $\mathrm{OD}_{600}=0.5$ each. 1 day after infiltration, Agrobacterium harboring SMV cDNA was infiltrated at $\mathrm{OD}_{600}=0.1$ for SMV inoculation.

RNase assay. $N$. benthamiana leaves expressing Rsv4-FLAG or D99N-FLAG were homogenized in an ice-cold buffer (30 mM HEPES- $\mathrm{KOH}$ pH 7.4, $100 \mathrm{mM} \mathrm{KCl}$, $2 \mathrm{mM}$ EDTA, $2 \mathrm{mM}$ DTT, 1 tablet per $50 \mathrm{ml}$ cOmplete EDTA-free Protease Inhibitor [Roche]) by using a grinder. After clarification by centrifugation $(800 \times g)$, the membrane fraction was pelleted by centrifugation at $16,000 \times g$ for 15 min. The pellet was suspended in homogenization buffer containing $1 \%$ Triton $\mathrm{X}-100$, and the solubilized proteins were purified using anti-FLAG antibody-conjugated agarose (SIGMA). FLAG-tagged proteins were eluted with $0.1 \mathrm{mg}$ per $\mathrm{ml}$ $3 \times$ FLAG peptide in $30 \mathrm{mM}$ HEPES-KOH pH 7.4, $100 \mathrm{mM} \mathrm{KCl}, 2 \mathrm{mM}$ DTT, $0.2 \%$ Triton X-100, $3 \mu \mathrm{g}$ per ml BSA, 1 tablet per $50 \mathrm{ml}$ cOmplete EDTA-free Protease Inhibitor (Roche). The eluate was mixed with an equal volume of glycerol and stored at $-30^{\circ} \mathrm{C}$. For substrate RNA production, pGEM-SMV-7610-7960 was constructed by inserting a SMV-C cDNA fragment amplified by PCR using primers SMV7610F and SMV7960R (Supplementary Data 2) into pGEM-7Zf( + ) between the ClaI and BamHI sites. Substrate RNA was transcribed from BamHIlinearized pGEM-SMV-7610-7960 using T7 RNA polymerase in the presence of $\left[\alpha^{-32} \mathrm{P}\right]$ CTP. A synthetic DNA (5'-GGTTCTCTAACATTTCTCTTCCAACCCAC CAGTCTTCCATGAAAA-3') or RNA transcribed from ClaI-linearized pGEMSMV-7610-7960 using SP6 RNA polymerase was annealed to the substrate. Digestion was performed in $30 \mathrm{mM}$ HEPES-KOH pH 7.4, $50 \mathrm{mM} \mathrm{KCl}, 2 \mathrm{mM}$ DTT, $0.1 \%$ Triton X-100 at $25^{\circ} \mathrm{C}$ for $30 \mathrm{~min} . \mathrm{MgCl}_{2}$ or $\mathrm{MnCl}_{2}$ was supplemented as indicated (Fig. 4a). E. coli RNase $\mathrm{H}$ and $\mathrm{S} 1$ nuclease were purchased from TaKaRa $\mathrm{Bio}$, and digestion was performed in $30 \mathrm{mM}$ HEPES-KOH pH 7.4, $50 \mathrm{mM} \mathrm{KCl}, 4$ $\mathrm{mM} \mathrm{MgCl} 2,2 \mathrm{mM}$ DTT, $0.1 \%$ Triton X-100 for RNase H or in the supplied buffer for S1 nuclease. After the reactions, RNA was purified and analyzed by $7 \mathrm{M}$ urea-10\% PAGE followed by autoradiography.

Interaction analyses of Rsv4 and SMV P3. Rsv4-FLAG and P3-Myc were coexpressed in $N$. benthamiana leaves by agroinfiltration. 3 days after infiltration, the leaves were homogenized in TR buffer ( $30 \mathrm{mM}$ HEPES-KOH pH 7.4, $80 \mathrm{mM}$ $\mathrm{KOAc}, 1.8 \mathrm{mM} \mathrm{Mg}(\mathrm{OAc})_{2}, 2 \mathrm{mM}$ DTT, 1 tablet per $50 \mathrm{ml}$ cOmplete EDTA-free Protease Inhibitor [Roche]). After clarification by centrifugation $(800 \times g)$, membranes were pelleted by $16,000 \times g$ for $15 \mathrm{~min}$. The pellet was suspended in TR buffer containing $1 \%$ Triton X-100, incubated with anti-FLAG antibody at $4{ }^{\circ} \mathrm{C}$ for $2 \mathrm{~h}$, washed four times with wash buffer (30 mM HEPES-KOH pH 7.4, $100 \mathrm{mM} \mathrm{NaCl}$, $2 \mathrm{mM}$ DTT, $0.2 \%$ Triton X-100, 1 tablet per $50 \mathrm{ml}$ cOmplete EDTA-free Protease Inhibitor [Roche]), and eluted with wash buffer containing $0.1 \mathrm{mg}$ per $\mathrm{ml} 3 \times$ FLAG peptide. The eluted samples were analyzed by western blotting using anti-Myc (Cat\#16286-1-AP: Cosmo Bio, Tokyo, Japan) and anti-DYKDDDDK (Cat\#01822381: Wako Pure Chemical, Osaka, Japan) antibodies diluted at 1:1000 in TBST containing $5 \%$ skim milk.

Viral RdRp assay. Membrane fractions of SMV-inoculated leaf extracts (6 days post-inoculation) and FLAG-purified fractions after solubilization that were prepared as described above were incubated with a template RNA ( $20 \mathrm{ng}$ per $\mu \mathrm{l}$ in vitro-transcribed SMV full-length genomic RNA) and $5 \times$ RdRp reaction solution (5 mM ATP, $5 \mathrm{mM}$ GTP, $5 \mathrm{mM}$ UTP, $62.5 \mu \mathrm{M}$ CTP, $25 \mathrm{mM} \mathrm{Mg}(\mathrm{OAc})_{2}, 50 \mathrm{mM}$ DTT, $0.5 \mathrm{mg}$ per $\mathrm{ml}$ actinomycin D, $4 \mathrm{U}$ per $\mu \mathrm{l}$ RNasin Plus [Promega], $1 \mathrm{mg}$ per $\mathrm{ml}$ creatine kinase, $100 \mathrm{mM}$ creatine phosphate, $370 \mathrm{MBq}$ per $\left.\mathrm{ml}\left[\alpha^{-32} \mathrm{P}\right] \mathrm{CTP}\right)$ at 
$25^{\circ} \mathrm{C}$ for $90 \mathrm{~min}$. Following phenol extraction and ethanol precipitation, singlestranded RNA was digested with S1 nuclease (TaKaRa Bio), and the remaining dsRNA was separated by $8 \mathrm{M}$ urea-2.4\% PAGE and detected by autoradiography.

Construction of RTL2-fusion proteins. RTL2, TIP1, and eIF(iso4E) cDNAs were amplified from Arabidopsis thaliana Col-0 RNA and TOM1 cDNA was amplified from Nicotiana tabacum cv. Samsun RNA using the primers listed in Supplementary Data 2. cDNAs for target proteins and RTL2 were fused by overlap PCR with ten glycine codons (GGT×10) as a linker and cloned into pMLH7133. As negative controls, a mutation causing D100A (GAT to GCT) of RTL2 was introduced into each fusion protein by site-directed mutagenesis, and RTL2 alone was cloned into pMLH7133. A mixture of Agrobacterium strains that express p19 and one of the fusion proteins $\left(\mathrm{OD}_{600}=0.2\right.$ and 0.5 , respectively) was infiltrated into $N$. benthamiana leaves using a needleless syringe. Two days after infiltration, ToMV, CMV, or TuMV was mechanically inoculated.

Diversity analysis. Multiple alignments of nucleotide and protein sequences were constructed using a progressive sequence alignment tool ${ }^{67}$ implemented in the CLC Genomics Workbench with default parameter values. A BLAST (blastp) search to find sequences similar to Rsv4 was performed against the nonredundant (nr) protein database maintained by NCBI with an $E$-value cutoff of $3 \mathrm{e}^{-10}$. A phylogenetic tree was constructed by neighbor joining with 1000 bootstrap replications based on 'Kimura 80' and 'Kimura protein' 68 genetic distances for nucleotide and protein sequences, respectively. Genome assemblies of azuki bean (Vigna angularis [Willd.] Ohwi and Ohashi), Vangularis v1; pigeon pea (Cajanus cajan [L] Millsp.), ICPL87119_v1; and common bean (Phaseolus vulgaris L.), Pvulgaris_218_v1.0, were obtained from the Vigna Genome Server (VigGS; https:// viggs.dna.affrc.go.jp), Legume Information System (LIS; https://legumeinfo.org/ organism/Cajanus/cajan), and Phytozome FTP site, respectively. Dot plot analysis $^{69}$ implemented in the CLC Genomics Workbench was used to find similar regions on the same chromosome, among orthologous soybean chromosomes, and between genomes of different species using default parameters and a window size of 9 .

Reporting summary. Further information on research design is available in the Nature Research Reporting Summary linked to this article.

\section{Data availability}

Data supporting the findings of this work are available within the paper and its Supplementary Information files. A reporting summary for this Article is available as a Supplementary Information file. The datasets generated and analyzed during the current study are available from the corresponding author upon request. The nucleotide sequences of SMV-C cDNA and Peking Rsv4 mRNA are deposited in DDBJ under accession numbers LC323107 and LC325439, respectively. The genomic DNA sequences for the Rsv4 regions of different soybean germplasms are deposited under accession numbers DDBJ LC325364 -LC325438 and GenBank accession numbers MN178650MN178656. The source data underlying Figs. 2b-f, 4a-d, 5a, and $6 \mathrm{~b}$ and Supplementary Figs. $3 c, 6 a$, and $6 \mathrm{~b}$ are provided as a Source Data file.

Received: 30 November 2018 Accepted: 13 August 2019

Published online: 27 September 2019

\section{References}

1. DeWitte-Orr, S. J. \& Mossman, K. L. dsRNA and the innate antiviral immune response. Future Virol. 5, 325-341 (2010).

2. Pumplin, N. \& Voinnet, O. RNA silencing suppression by plant pathogens: defence, counter-defence and counter-counter-defence. Nat. Rev. Micro. 11, 745-760 (2013).

3. De Ronde, D., Butterbach, P. \& Kormelink, R. Dominant resistance against plant viruses. Front Plant Sci. 5, 307 (2014).

4. Revers, F. \& García, J. A. In Advances in Virus Research Vol. 92 (eds Maramorosch, K. \& Mettenleiter, T. C.) 101-199 (Academic Press, 2015).

5. Solomon-Blackburn, R. M. \& Barker, H. Breeding virus resistant potatoes (Solanum tuberosum): a review of traditional and molecular approaches. Heredity 86, 17-35 (2001).

6. Kyle, M. M. \& Palloix, A. Proposed revision of nomenclature for potyvirusresistance genes in Capsicum. Euphytica 97, 183-188 (1997).

7. Sharma, S. K. \& Tripathi, S. In Plant Virus-Host Interaction (eds Gaur, R. K., Hohn, T. \& Sharma, P.) 177-194 (Academic Press, Boston, 2014).

8. Hartmann, W. \& Neumüller, M. Breeding for resistance: breeding for Plum pox virus resistant plums (Prunus domestica L.) in Germany. EPPO Bull. 36, 332-336 (2006).

9. Li, G. et al. TuMV management for brassica crops through host resistance: retrospect and prospects. Plant Pathol. 68, 1035-1044 (2019).
10. Jain, S., McPhee, K., Kumar, A., Rouf Mir, R. \& Singh, R. In Agricultural Sustainability (eds Bhullar, G. S. \& Bhullar, N. K.) 221-244 (Academic Press, San Diego, 2013).

11. Ross, J. P. Effect of aphid-transmitted soybean mosaic virus on yields of closely related resistant and susceptible soybean lines. Crop Sci. 17, 869-872 (1977).

12. Hajimorad, M. R., Domier, L. L., Tolin, S. A., Whitham, S. A. \& Saghai Maroof, M. A. Soybean mosaic virus: a successful potyvirus with a wide distribution but restricted natural host range. Mol. Plant Pathol. 19, 1563-1579 (2018).

13. Hajimorad, M. R. \& Hill, J. H. Rsv1-mediated resistance against Soybean mosaic virus- $\mathrm{N}$ is hypersensitive response-independent at inoculation site, but has the potential to initiate a hypersensitive response-like mechanism. Mol. Plant Microbe Interact. 14, 587-598 (2001).

14. Suh, S. J. et al. The Rsv3 locus conferring resistance to Soybean mosaic virus is associated with a cluster of coiled-coil nucleotide-binding leucine-rich repeat genes. Plant Gen. 4, 55-64 (2011).

15. Cho, E.-K. \& Goodman, R. M. Strains of soybean mosaic virus: classification based on virulence in resistant soybean cultivars. Phytopathology 69, 467-470 (1979).

16. Klepadlo, M. et al. Two tightly linked genes for soybean mosaic virus resistance in soybean. Crop Sci. 57, 1844-1853 (2017).

17. Tran, P.-T., Widyasari, K., Seo, J.-K. \& Kim, K.-H. Isolation and validation of a candidate $R s v 3$ gene from a soybean genotype that confers strain-specific resistance to soybean mosaic virus. Virology 513, 153-159 (2018).

18. Gunduz, I., Buss, G. R., Chen, P. \& Tolin, S. A. Genetic and phenotypic analysis of Soybean mosaic virus resistance in PI 88788 soybean. Phytopathology 94, 687-692 (2004).

19. Saghai Maroof, M. A. et al. Fine mapping and candidate gene discovery of the soybean mosaic virus resistance gene, Rsv4. Plant Gen. 3, 14-22 (2010).

20. Wang, D. et al. Fine mapping and analyses of $R_{S C 8}$ resistance candidate genes to soybean mosaic virus in soybean. Theor. Appl. Genet. 122, 555-565 (2011)

21. Ilut, D. C. et al. Identification of haplotypes at the Rsv4 genomic region in soybean associated with durable resistance to soybean mosaic virus. Theor. Appl. Genet. 129, 453-468 (2016).

22. Chowda-Reddy, R. V. et al. Mutations in the P3 protein of Soybean mosaic virus G2 isolates determine virulence on Rsv4-genotype soybean. Mol. Plant Microbe Interact. 24, 37-43 (2011).

23. Shakiba, E. et al. Inheritance and allelic relationships of resistance genes for Soybean mosaic virus in 'Corsica' and 'Beeson' soybean. Crop Sci. 53, 1455-1463 (2013).

24. Nowotny, M., Gaidamakov, S. A., Crouch, R. J. \& Yang, W. Crystal structures of RNase $\mathrm{H}$ bound to an RNA/DNA hybrid: substrate specificity and metaldependent catalysis. Cell 121, 1005-1016 (2005).

25. Buck, K. W. In Advances in Virus Research (eds Maramorosch, K., Murphy, F. A. \& Shatkin, A. J.) 159-251 (Academic Press, 1996).

26. den Boon, J. A. \& Ahlquist, P. Organelle-like membrane compartmentalization of positive-strand RNA virus replication factories. Annu. Rev. Microbiol. 64, 241-256 (2010).

27. Paul, D. \& Bartenschlager, R. Architecture and biogenesis of plus-strand RNA virus replication factories. World J. Virol. 2, 32-48 (2013).

28. Ahangaran, A., Habibi, M. K., Mohammadi, G.-H. M., Winter, S. \& GarcíaArenal, F. Analysis of Soybean mosaic virus genetic diversity in Iran allows the characterization of a new mutation resulting in overcoming Rsv4-resistance. J. Gen. Virol. 94, 2557-2568 (2013).

29. Khatabi, B., Fajolu, O. L., Wen, R. H. \& Hajimorad, M. R. Evaluation of North American isolates of Soybean mosaic virus for gain of virulence on Rsvgenotype soybeans with special emphasis on resistance-breaking determinants on Rsv4. Mol. Plant Pathol. 13, 1077-1088 (2012).

30. Wang, Y., Khatabi, B. \& Hajimorad, M. R. Amino acid substitution in P3 of Soybean mosaic virus to convert avirulence to virulence on Rsv4-genotype soybean is influenced by the genetic composition of P3. Mol. Plant Pathol. 16, 301-307 (2015).

31. Merits, A., Guo, D., Järvekülg, L. \& Saarma, M. Biochemical and genetic evidence for interactions between potato A potyvirus-encoded proteins P1 and P3 and proteins of the putative replication complex. Virology 263, 15-22 (1999).

32. Guo, D., Rajamäki, M.-L., Saarma, M. \& Valkonen, J. P. T. Towards a protein interaction map of potyviruses: protein interaction matrixes of two potyviruses based on the yeast two-hybrid system. J. Gen. Virol. 82, 935-939 (2001).

33. Cui, X. et al. The C-terminal region of the Turnip mosaic virus $\mathrm{P} 3$ protein is essential for viral infection via targeting P3 to the viral replication complex. Virology 510, 147-155 (2017).

34. Wylie, S. J. et al. ICTV virus taxonomy profile: Potyviridae. J. Gen. Virol. 98, 352-354 (2017).

35. Kiyota, E. et al. An Arabidopsis RNase III-like protein, AtRTL2, cleaves double-stranded RNA in vitro. J. Plant Res. 124, 405-414 (2011). 
36. Yamanaka, T. et al. TOM1, an Arabidopsis gene required for efficient multiplication of a tobamovirus, encodes a putative transmembrane protein. Proc. Natl Acad. Sci. USA 97, 10107-10112 (2000).

37. Kim, M. J., Kim, H. R. \& Paek, K.-H. Arabidopsis tonoplast proteins TIP1 and TIP2 interact with the cucumber mosaic virus 1a replication protein. J. Gen. Virol. 87, 3425-3431 (2006).

38. Beauchemin, C., Boutet, N. \& Laliberté, J.-F. Visualization of the interaction between the precursors of VPg, the viral protein linked to the genome of Turnip mosaic virus, and the translation eukaryotic initiation factor iso $4 \mathrm{E}$ in planta. J. Virol. 81, 775-782 (2007).

39. Ishibashi, K., Naito, S., Meshi, T. \& Ishikawa, M. An inhibitory interaction between viral and cellular proteins underlies the resistance of tomato to nonadapted tobamoviruses. Proc. Natl Acad. Sci. USA 106, 8778-8783 (2009).

40. Ishibashi, K., Masuda, K., Naito, S., Meshi, T. \& Ishikawa, M. An inhibitor of viral RNA replication is encoded by a plant resistance gene. Proc. Natl Acad. Sci. USA 104, 13833-13838 (2007).

41. Yoshida, T. et al. The plant non-canonical antiviral resistance protein JAX1 inhibits potexviral replication by targeting the viral RNA-dependent RNA polymerase. J. Virol. 93, e01506-e01518 (2018).

42. Liu, Q. et al. An atypical thioredoxin imparts early resistance to Sugarcane mosaic virus in maize. Mol. Plant 10, 483-497 (2017).

43. Chisholm, S. T., Parra, M. A., Anderberg, R. J. \& Carrington, J. C. Arabidopsis RTM1 and RTM2 genes function in phloem to restrict long-distance movement of tobacco etch virus. Plant Physiol. 127, 1667-1675 (2001).

44. Whitham, S. A., Anderberg, R. J., Chisholm, S. T. \& Carrington, J. C. Arabidopsis RTM2 gene is necessary for specific restriction of tobacco etch virus and encodes an unusual small heat shock-like protein. Plant Cell 12, 569-582 (2000).

45. Cosson, P. et al. RTM3, which controls long-distance movement of potyviruses, is a member of a new plant gene family encoding a meprin and TRAF homology domain-containing protein. Plant Physiol. 154, 222-232 (2010).

46. Wang, Q. et al. STV11 encodes a sulphotransferase and confers durable resistance to rice stripe virus. Nat. Commun. 5, 4768 (2014).

47. Verlaan, M. G. et al. The tomato yellow leaf curl virus resistance genes $T y-1$ and $T y$-3 are allelic and code for DFDGD-class RNA-dependent RNA polymerases. PLoS Genet. 9, e1003399 (2013).

48. Butterbach, P. et al. Tomato yellow leaf curl virus resistance by $T y-1$ involves increased cytosine methylation of viral genomes and is compromised by cucumber mosaic virus infection. Proc. Natl Acad. Sci. USA 111, 12942-12947 (2014).

49. Wang, Y. \& Hajimorad, M. R. Gain of virulence by Soybean mosaic virus on Rsv4-genotype soybeans is associated with a relative fitness loss in a susceptible host. Mol. Plant Pathol. 17, 1154-1159 (2016).

50. Abel, P. et al. Delay of disease development in transgenic plants that express the tobacco mosaic virus coat protein gene. Science 232, 738-743 (1986).

51. Pooggin, M. M. RNAi-mediated resistance to viruses: a critical assessment of methodologies. Curr. Opin. Virol. 26, 28-35 (2017).

52. Lindbo, J. A. \& Falk, B. W. The impact of "coat protein-mediated virus resistance" in applied plant pathology and basic research. Phytopathology 107, 624-634 (2017).

53. Kreuze, J. F. \& Valkonen, J. P. T. Utilization of engineered resistance to viruses in crops of the developing world, with emphasis on sub-Saharan Africa. Curr. Opin. Virol. 26, 90-97 (2017).

54. Gal-On, A., Fuchs, M. \& Gray, S. Generation of novel resistance genes using mutation and targeted gene editing. Curr. Opin. Virol. 26, 98-103 (2017).

55. Kaga, A. et al. Evaluation of soybean germplasm conserved in NIAS genebank and development of mini core collections. Breed. Sci. 61, 566-592 (2012).

56. Shi, A., Chen, P., Zheng, C., Hou, A. \& Zhang, B. A PCR-based marker for the Rsv1 locus conferring resistance to Soybean mosaic virus. Crop Sci. 48, 262-268 (2008).

57. Rozen, S. \& Skaletsky, H. In Bioinformatics Methods and Protocols (eds Misener, S. \& Krawetz, S. A.) 365-386 (Humana Press, Totowa, 1999).

58. Schmutz, J. et al. Genome sequence of the paleopolyploid soybean. Nature 463, 178-183 (2010).

59. Andreson, R., Reppo, E., Kaplinski, L. \& Remm, M. GENOMEMASKER package for designing unique genomic PCR primers. BMC Bioinformatics 7, 172 (2006).

60. Khosla, S., Augustus, M. \& Brahmachari, V. Sex-specific organisation of middle repetitive DNA sequences in the mealybug Planococcus lilacinus. Nucleic Acids Res. 27, 3745-3751 (1999).

61. Ooijen, J. W. JoinMap 4.0: software for the calculation of genetic linkage maps in experimental populations (Kyazma BV, Wageningen, Netherlands, 2006).
62. Schneider, C. A., Rasband, W. S. \& Eliceiri, K. W. NIH Image to ImageJ: 25 years of image analysis. Nat. Methods 9, 671-675 (2012).

63. Liu, B. et al. The soybean stem growth habit gene Dt1 is an ortholog of arabidopsis TERMINAL FLOWER1. Plant Physiol. 153, 198-210 (2010).

64. Nishizawa, K., Kita, Y., Kitayama, M. \& Ishimoto, M. A red fluorescent protein, DsRed2, as a visual reporter for transient expression and stable transformation in soybean. Plant Cell Rep. 25, 1355-1361 (2006).

65. Tsuda, M. et al. Construction of a high-density mutant library in soybean and development of a mutant retrieval method using amplicon sequencing. BMC Genomics 16, 1014 (2015).

66. Mitsuhara, I. et al. Efficient promoter cassettes for enhanced expression of foregin genes in dicotyledonous and monocotyledonous plants. Plant Cell Physiol. 37, 49-59 (1996).

67. Feng, D.-F. \& Doolittle, R. F. Progressive sequence alignment as a prerequisitetto correct phylogenetic trees. J. Mol. Evol. 25, 351-360 (1987).

68. Kimura, M. A simple method for estimating evolutionary rates of base substitutions through comparative studies of nucleotide sequences. J. Mol. Evol. 16, 111-120 (1980).

69. Maizel, J. V. \& Lenk, R. P. Enhanced graphic matrix analysis of nucleic acid and protein sequences. Proc. Natl Acad. Sci. USA 78, 7665-7669 (1981).

\section{Acknowledgements}

We thank S. Namba, Y. Yamaji, K. Maejima, and the Genetic Resources Center, NARO, for providing leaves infected with PPV and other potyviruses. This work was supported in part by a grant from the Ministry of Agriculture, Forestry and Fisheries of Japan (Genomics-based Technology for Agricultural Improvement, SFC-1008) and from the Genebank Project, NARO.

\section{Author contributions}

K.I. and A.K. designed the work. M. Saruta, T.S., N.Y., Y.K., and A.K. performed positional cloning of Rsv4. M. Ishimoto and K.K. developed transgenic soybeans expressing Rsv4. T.A. and A.K. identified Rsv4 mutant lines. K.I. and M. Shu performed agroinfiltration-mediated $N$. benthamiana transient assays. K.I. assayed the activities of Rsv4 and potyviral RdRp. K.I., M. Ishikawa, M. Ishimoto, and A.K. coordinated and supervised the work and analyzed the data. K.I., M. Ishikawa, and A.K. wrote the paper.

\section{Additional information}

Supplementary Information accompanies this paper at https://doi.org/10.1038/s41467 019-12052-5.

Competing interests: Patent applications have been filed by the National Agriculture and Food Research Organization relating to work in this study. Patent number WO/ 2016/148074 is claimed by K.I., M. Saruta, T.S., M. Ishikawa, M. Ishimoto, and A.K. Patent number JP,2018-191622,A is claimed by K.I.

Reprints and permission information is available online at http://npg.nature.com/ reprintsandpermissions/

Peer review information: Nature Communications thanks Kristiina Mäkinen, and the other, anonymous, reviewer(s) for their contribution to the peer review of this work.

Publisher's note: Springer Nature remains neutral with regard to jurisdictional claims in published maps and institutional affiliations.

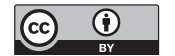

Open Access This article is licensed under a Creative Commons Attribution 4.0 International License, which permits use, sharing, adaptation, distribution and reproduction in any medium or format, as long as you give appropriate credit to the original author(s) and the source, provide a link to the Creative Commons license, and indicate if changes were made. The images or other third party material in this article are included in the article's Creative Commons license, unless indicated otherwise in a credit line to the material. If material is not included in the article's Creative Commons license and your intended use is not permitted by statutory regulation or exceeds the permitted use, you will need to obtain permission directly from the copyright holder. To view a copy of this license, visit http://creativecommons.org/ licenses/by/4.0/.

(C) The Author(s) 2019 